\title{
Penerapan model pembelajaran kooperatif tipe stad untuk meningkatkan ketuntasan belajar siswa pada pokok bahasan termokimia
}

\section{Application of cooperative learning model type stad to increase student learning in these thermochemical}

Fauziah $^{1 *}$

${ }^{1}$ Guru Kimia, Madrasah Aliyah Negeri 2 Model, Medan-Indonesia

*Korespondensi: fauziahsarumpaet@yahoo.com

\begin{abstract}
Penelitian ini bertujuan untuk mengetahui apakah penerapan model pembelajaran kooperatif STAD efektif digunakan dalam meningkatkan ketuntasan belajar kimia siswa, dan bagaimana ketuntasan belajar kimia siswa pada pokok bahasan termokimia setelah penerapan model pembelajaran kooperatif STAD. Penelitian ini merupakan Penelitian Tindakan Kelas. Hasil penelitian terbukti bahwa penerapan model pembelajaran kooperatif STAD efektif digunakan dalam meningkatkan ketuntasan belajar kimia siswa pada pokok bahasan termokimia. Rata-rata hasil belajar siswa pada siklus I sebesar 74,49 dengan tingkat ketuntasan hasil belajar sebesar 82,05\% (belum tuntas secara klasikal), setelah dilakukan pembelajaran siklus II dari tes hasil belajar diperoleh rata-rata hasil belajar siswa sebesar 80,38 dengan tingkat ketuntasan hasil belajar siswa sebesar 100\% (telah tuntas secara klasikal). Aktivitas belajar siswa selama pembelajaran dari siklus I hingga siklus II dengan menerapkan model pembelajaran kooperatif STAD mengalami peningkatan. Dengan demikian dari hasil penelitian ini diharapkan para guru khususnya guru kimia melakukan kerja kolaboratif dalam PTK sebagai wahana pengembangan profesionalisme guru dalam pembelajaran dan sudah waktunya untuk menggunakan pembelajaran yang inovatif, seperti model pembelajaran kooperatif tipe STAD.
\end{abstract}

Kata kunci: ketuntasan belajar siswa, model pembelajaran kooperatif tipe STAD, PTK

\begin{abstract}
This study aims to determine whether the application of STAD cooperative learning model is effectively used in improving students learning mastery, and how the students chemistry learning mastery on thermochemical subject after application of STAD cooperative learning model. This research is a Classroom Action Research.The results of research proved that the application of STAD cooperative learning model effectively used in improving students' chemistry learning mastery on thermo-chemical subject. Average learning outcomes of students in the first cycle of 74.49 with the completeness level of learning results of $82.05 \%$ (not completed in a classical), after the learning cycle II of the test results obtained learning average student learning outcome of 80.38 with a mastery level of student learning outcomes of $100 \%$ (completed thoroughly in classical). Student learning activities during learning from cycle I to cycle II by applying STAD cooperative learning model has increased. Thus, the results of this study are expected teachers especially chemistry teachers do collaborative work in the PTK as a vehicle for the development of professionalism of teachers in learning and it's time to use innovative learning, such as STAD type cooperative learning model.
\end{abstract}

Key words: student learning mastery, cooperative learning model type STAD, PTK

DOI: https://doi.org/10.24114/jpkim.v9i3.8384

Kimia merupakan salah satu bidang studi yang dianggap kurang menarik dan sulit dipahami siswa. Rusmansyah (2001) mengemukakan bahwa "ilmu kimia merupakan salah satu mata pelajaran tersulit bagi kebanyakan siswa menengah dan mahasiswa". Kesulitan mempelajari kimia itu terkait dengan ciri-ciri ilmu kimia seperti yang disebutkan oleh Kean dan Middle Camp (dalam Rusmansyah, 2001) bahwa: (1) sebagian besar ilmu kimia bersifat abstrak; (2) ilmu kimia merupakan 
penyederhanaan dari yang sebenarnya; (3) Sifat ilmu kimia berurutan dan berkembang dengan cepat; (4) Ilmu kimia tidak sekedar memecahkan soal-soal; dan (5) Bahan atau materi yang dipelajari dalam kimia sangat banyak.

Banyaknya konsep kimia yang bersifat abstrak yang harus diserap siswa dalam waktu relatif terbatas menjadikan ilmu kimia merupakan salah satu mata pelajaran tersulit bagi siswa saat ini. Akibatnya, banyak siswa Sekolah Menengah Umum (SMU) yang gagal dalam belajar kimia (Rusmansyah, 2001; Silaban \& Simangunsong, 2015; Manalu dkk., 2016). Hasil penelitian yang dilakukan oleh Pendley, Bretz dan Novack 1994 (dalam Rusmansyah, 2001) menunjukkan bahwa pada umumnya siswa cenderung belajar dengan hafalan dari pada secara aktif mencari untuk membangun pemahaman mereka sendiri terhadap konsep kimia. Menurut Nakhleh 1992 (dalam Rusmansyah, 2001), hal tersebut menyebabkan sebagian besar konsep-konsep kimia masih merupakan konsep yang abstrak bagi siswa, dan bahkan mereka tidak dapat mengenali konsepkonsep kunci atau hubungan antar konsep yang diperlukan untuk memahami konsep tersebut. Akibatnya, siswa tidak membangun pemahaman konsep-konsep kimia yang fundamental pada awal mereka belajar kimia.

Banyak cara yang dapat digunakan untuk mempengaruhi proses belajar menjadi dinamis dan efektif, diantaranya dengan menimbulkan motivasi dan keterlibatan siswa secara langsung dalam belajar. Salah satu cara untuk dapat menumbuhkan semangat dan keterlibatan siswa dalam belajar sebagai upaya meningkatkan hasil belajar siswa adalah dengan menggunakan model pembelajaran kooperatif. Pembelajaran kooperatif adalah model pembelajaran yang menekankan kepada proses kerja sama dalam suatu kelompok yang bisa terdiri dari 4 sampai 5 orang siswa untuk mempelajari suatu materi pelajaran sampai tuntas. Melalui pembelajaran kooperatif siswa didorong untuk bekerja sama secara maksimal sesuai dengan keadaan kelompoknya.

Ada empat pendekatan yang biasa digunakan dalam pembelajaran kooperatif yaitu: Student Teams Achievement Division (STAD), Jigsaw, Investigasi Kelompok (IK) dan Pendekatan Struktural. Pembelajaran STAD, mengacu kepada belajar kelompok siswa, menyajikan informasi akademik baru kepada siswa setiap minggu menggunakan presentasi verbal atau teks. Siswa dalam suatu kelas tertentu dipecah menjadi kelompok dengan anggota 4-5 orang, setiap kelompok haruslah heterogen, terdiri dari laki-laki dan perempuan, tinggi, sedang, dan rendah.
Anggota tim menggunakan lembar kegiatan atau perangkat pembelajaran yang lain untuk menuntaskan materi pelajarannya dan kemudian saling membantu satu sama lain untuk memahami bahan pelajaran melalui tutorial, kuis, atau melakukan diskusi. Diharapkan dengan pembelajaran STAD dapat meningkatkan motivasi, minat dan rasa percaya siswa dalam belajar kimia, dan diharapkan dapat meningkatkan kekompakan untuk menuntaskan materi pelajaran dengan kerjasama.

Berdasarkan uraian di atas, untuk menjawab permasalahan yang ada maka masalah ini penting untuk diteliti melalui suatu penelitian tindakan kelas dengan judul Penerapan model pembelajaran kooperatif tipe stad untuk meningkatkan ketuntasan belajar siswa klas XI pada pokok bahasan termokimia MAN 2 model Medan".

\section{Metode}

\section{Objek Tindakan}

Penelitian ini merupakan Penelitian Tindakan Kelas. Adapun jenis tindakan yang diteliti adalah sebagai berikut:

1. Motivasi siswa untuk belajar dan berkerjasama dalam kelompok

2. Kerjasama dalam mengkomunikasikan hasil belajarnya, dan

3. Keaktifan dan sikap kooperatif siswa selama mengikuti pembelajaran

\section{Subjek Penelitian}

Lokasi Penelitian Tindakan Kelas (PTK) ini adalah MAN 2 Model Medan, kelas XI IPA dengan jumlah siswa 39 orang. Mata pelajaran Kimia, pada pokok bahasan Termokimia.

\section{Prosedur Penelitian}

Penelitian ini langsung dilakukan di dalam kelas meliputi kegiatan pelaksanaan PTK berupa refleksi awal dan observasi untuk mengidentifikasi permasalahan yang terjadi di kelas. Pelaksanaan PTK dilakukan sebanyak 2 siklus (Gbr 1).

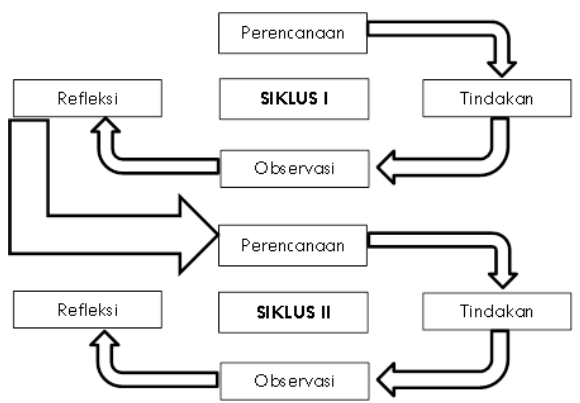

Gbr 1. Rancangan prosedur penelitian tindakan kelas. 


\section{Hasil dan Pembahasan}

\section{Siklus I}

Dalam proses pembelajaran siklus pertama pengenalan materi dilakukan dengan diskusi kelas, kemudian dilanjutkan dengan diskusi kelompok yang materinya dikembangkan dari LKS. Hasil penelitiannya adalah sebagai berikut:

Tabel 1

Tingkat penguasaan siswa pada siklus I

\begin{tabular}{cccrl}
\hline Nilai & TP & F & \multicolumn{1}{c}{$\%$} & Keterangan \\
\hline 60 & $60 \%$ & 7 & 17,95 & Kurang \\
65 & $65 \%$ & 1 & 2,56 & Cukup \\
70 & $70 \%$ & 7 & 17,95 & Cukup \\
75 & $75 \%$ & 9 & 23,08 & Cukup \\
80 & $80 \%$ & 10 & 25,64 & Baik \\
85 & $85 \%$ & 1 & 2,56 & Baik \\
90 & $90 \%$ & 2 & 5,13 & Baik Sekali \\
95 & $95 \%$ & 2 & 5,13 & Baik Sekali \\
\hline \multicolumn{5}{c}{ Jumlah } \\
Mean & 39 & $100 \%$ & \\
\hline \multicolumn{5}{c}{74,49} \\
\hline
\end{tabular}

Tabel 1 di atas menunjukkan bahwa rata-rata hasil belajar siswa pada siklus I sebesar 74,49. Berdasarkan tingkat penguasaan (TP) $17,95 \%$ siswa yang memiliki tingkat penguasaan yang tergolong kurang; $43,59 \%$ yang tergolong cukup; $28,2 \%$ yang tergolong baik dan $10,26 \%$ siswa yang memiliki tingkat penguasaan sangat baik. Berdasarkan tingkat ketuntasan belajar menunjukkan $17,95 \%$ siswa yang belum tuntas dan $82,05 \%$ yang telah tuntas. Dengan demikian secara kelas dikatakan siswa belum mencapai ketuntasan belajar.

Selanjutnya aktivitas belajar siswa dan aktivitas guru berdasarkan hasil pengamatan yang dilakukan dua orang teman sejawat, diperoleh hasil seperti pada Tabel 2 dan Tabel 3.

Tabel 2

Aktivitas belajar siswa pada siklus I

\begin{tabular}{|c|c|c|c|c|}
\hline \multirow{3}{*}{$\begin{array}{c}\text { Kategori Aspek yang } \\
\text { Diamati }\end{array}$} & \multicolumn{4}{|c|}{ Siswa yang Aktif } \\
\hline & \multicolumn{2}{|c|}{ Pengamat I } & \multicolumn{2}{|c|}{ Pengamat II } \\
\hline & $f$ & $\%$ & $f$ & $\%$ \\
\hline $\begin{array}{l}\text { Mendengarkan/mempe } \\
\text { rhatikan penjelasan } \\
\text { guru }\end{array}$ & 32 & 82,1 & 35 & 89,7 \\
\hline $\begin{array}{l}\text { Membaca materi } \\
\text { pelajaran }\end{array}$ & 36 & 92,3 & 37 & 94,9 \\
\hline $\begin{array}{l}\text { Bekerjasama dengan } \\
\text { teman kelompok }\end{array}$ & 27 & 69,2 & 27 & 69,2 \\
\hline $\begin{array}{l}\text { Aktif menjawab } \\
\text { pertanyaan guru }\end{array}$ & 28 & 71,8 & 27 & 69,2 \\
\hline $\begin{array}{l}\text { Interaksi siswa dalam } \\
\text { diskusi/bertanya }\end{array}$ & 28 & 71,8 & 30 & 76,9 \\
\hline $\begin{array}{l}\text { Antusias memecahkan } \\
\text { masalah pada LKS }\end{array}$ & 30 & 76,9 & 31 & 79,5 \\
\hline $\begin{array}{l}\text { Memberikan } \\
\text { ide/tanggapan }\end{array}$ & 30 & 76,9 & 32 & 82,1 \\
\hline $\begin{array}{l}\text { Menyelesaikan tugas } \\
\text { mandiri/kuis }\end{array}$ & 27 & 69,2 & 28 & 71,8 \\
\hline Rata-rata & 30 & 76,9 & 31 & 79,5 \\
\hline
\end{tabular}

Tabel 3.

Aktivitas guru selama pembelajaran pada siklus I

\begin{tabular}{lll}
\hline \multicolumn{1}{c}{$\begin{array}{c}\text { Kategori Aspek yang } \\
\text { Diamati }\end{array}$} & $\begin{array}{l}\text { Pengamat } \\
\text { I }\end{array}$ & $\begin{array}{l}\text { Pengamat } \\
\text { II }\end{array}$ \\
\hline $\begin{array}{l}\text { Penampilan mengajar } \\
\text { Penyajian materi dari } \\
\text { segi: }\end{array}$ & Baik & Baik \\
$-\quad$ Inisiasi & Baik & $\begin{array}{l}\text { Sangat } \\
\text { Baik } \\
\text { Baik }\end{array}$ \\
- Pengembangan & Baik & Baik \\
Konsep & Bemandu Kegiatan & Baik \\
$\quad \begin{array}{l}\text { Aplikasi Konsep } \\
\text { - Pemantapan Konsep }\end{array}$ & Baik & Cukup \\
- Cara & Cukup & Cunilaian/Pengharga \\
$\quad$ an & & Baik \\
$\begin{array}{l}\text { Bagaimana guru } \\
\text { berinteraksi dengan } \\
\text { siswa }\end{array}$ & Baik & \\
$\begin{array}{l}\text { Memotivasi siswa dalam } \\
\text { diskusi kelompok }\end{array}$ & Baik & Baik \\
\hline
\end{tabular}

Interpretasi

Pengenalan materi perlu diperjelas dalam kelompok dan sebaiknya disampaikan oleh anggota kelompok. Karena materi awal belum begitu dikuasai, akibatnya proses pembelajaran belum maksimal dan peran siswa dalam pembelajaran masih kurang nampak.

\section{Siklus II}

Pengenalan materi dilakukan guru melalui diskusi kelas yang selanjutnya dilakukan pada kelompok oleh anggota kelompok yang menguasai materi, kemudian dikembangkan dengan pembahasan hasil lain dalam kelompok melalui tugas-tugas (LKS) yang diberikan. Hasil penelitiannya adalah sebagai berikut:

Tabel 4

Tingkat penguasaan siswa pada siklus II

\begin{tabular}{|c|c|c|c|c|}
\hline Nilai & TP & $\mathrm{F}$ & $\%$ & Keterangan \\
\hline 65 & $65 \%$ & 1 & 2,56 & Cukup \\
\hline 70 & $70 \%$ & 3 & 7,69 & Cukup \\
\hline 75 & $75 \%$ & 7 & 17,95 & Cukup \\
\hline 80 & $80 \%$ & 15 & 38,46 & Baik \\
\hline 85 & $85 \%$ & 7 & 17,95 & Baik \\
\hline 90 & $90 \%$ & 6 & 15,38 & Baik Sekali \\
\hline \multicolumn{2}{|c|}{ Jumlah } & 39 & 100 & \\
\hline \multicolumn{2}{|c|}{ Mean } & \multicolumn{3}{|c|}{80,38} \\
\hline
\end{tabular}

Tabel 4 di atas menunjukkan bahwa rata-rata hasil belajar siswa pada siklus II sebesar 80,38 . Berdasarkan tingkat penguasaan (TP) $28,21 \%$ siswa yang memiliki tingkat penguasaan yang tergolong cukup; $56,41 \%$ yang tergolong baik dan $15,38 \%$ siswa yang memiliki tingkat penguasaan sangat baik. Berdasarkan tingkat ketuntasan 
belajar menunjukkan seluruh siswa (100\%) yang telah tuntas dengan nilai $\geq 65 \%$. Dengan demikian secara kelas dikatakan siswa telah mencapai ketuntasan belajar.

Selanjutnya aktivitas belajar siswa pada siklus Il berdasarkan hasil pengamatan yang dilakukan dua orang teman sejawat, diperoleh hasil seperti pada Tabel 5 dan Tabel 6.

Tabel 5

Aktivitas belajar siswa pada siklus II

\begin{tabular}{lcccc}
\hline \multirow{2}{*}{$\begin{array}{l}\text { Kategori Aspek yang } \\
\text { Diamati }\end{array}$} & \multicolumn{4}{c}{ Siswa yang Aktif } \\
\cline { 2 - 5 } & \multicolumn{2}{c}{ Pengamat I } & \multicolumn{3}{c}{ Pengamat II } \\
\cline { 2 - 5 } & $\mathrm{f}$ & $\%$ & $\mathrm{f}$ & $\%$ \\
\hline $\begin{array}{l}\text { Mendengarkan/mempe } \\
\text { rhatikan penjelasan }\end{array}$ & 39 & 100 & 39 & 100 \\
$\begin{array}{l}\text { guru } \\
\begin{array}{l}\text { Membaca materi } \\
\text { pelajaran }\end{array}\end{array}$ & 38 & 97,4 & 37 & 94,9 \\
$\begin{array}{l}\text { Bekeriasama dengan } \\
\text { teman kelompok }\end{array}$ & 39 & 100 & 39 & 100 \\
$\begin{array}{l}\text { Aktif menjawab } \\
\text { pertanyaan guru }\end{array}$ & 37 & 94,9 & 38 & 97,4 \\
$\begin{array}{l}\text { Interaksi siswa dalam } \\
\text { diskusi/bertanya }\end{array}$ & 37 & 94,9 & 35 & 89,7 \\
$\begin{array}{l}\text { Antusias memecahkan } \\
\text { masalah pada LKS }\end{array}$ & 38 & 97,4 & 39 & 79,5 \\
$\begin{array}{l}\text { Memberikan } \\
\text { ide/tanggapan }\end{array}$ & 33 & 84,6 & 33 & 84,6 \\
$\begin{array}{l}\text { Menyelesaikan tugas } \\
\text { mandiri/kuis }\end{array}$ & 39 & 100 & 39 & 100 \\
\hline \begin{tabular}{l} 
Rata-rata \\
\hline
\end{tabular} & 38 & 97,4 & 37 & 94,9 \\
\hline
\end{tabular}

Tabel 6

Aktivitas guru selama pembelajaran pada siklus II

\begin{tabular}{|c|c|c|}
\hline $\begin{array}{c}\text { Kategori Aspek yang } \\
\text { Diamati }\end{array}$ & $\begin{array}{l}\text { Pengamat } \\
\text { I }\end{array}$ & $\begin{array}{l}\text { Pengamat } \\
\text { II }\end{array}$ \\
\hline Penampilan mengajar & Baik & $\begin{array}{l}\text { Sangat } \\
\text { Baik }\end{array}$ \\
\hline \multicolumn{3}{|l|}{$\begin{array}{l}\text { Penyajian materi dari } \\
\text { segi : }\end{array}$} \\
\hline - Inisiasi & Baik & $\begin{array}{l}\text { Sangat } \\
\text { Baik }\end{array}$ \\
\hline $\begin{array}{l}\text { - Pengembangan } \\
\text { Konsep }\end{array}$ & Baik & Baik \\
\hline $\begin{array}{l}\text { - Memandu Kegiatan } \\
\text { Aplikasi Konsep }\end{array}$ & $\begin{array}{l}\text { Sangat } \\
\text { Baik }\end{array}$ & $\begin{array}{l}\text { Sangat } \\
\text { Baik }\end{array}$ \\
\hline - Pemantapan Konsep & $\begin{array}{l}\text { Sangat } \\
\text { Baik }\end{array}$ & $\begin{array}{l}\text { Sangat } \\
\text { Baik }\end{array}$ \\
\hline $\begin{array}{l}\text { - Cara } \\
\text { Penilaian/Pengharg } \\
\text { aan }\end{array}$ & Cukup & Baik \\
\hline $\begin{array}{l}\text { Bagaimana guru } \\
\text { berinteraksi dengan } \\
\text { siswa }\end{array}$ & Baik & Baik \\
\hline $\begin{array}{l}\text { Memotivasi siswa dalam } \\
\text { diskusi kelompok }\end{array}$ & Baik & Baik \\
\hline
\end{tabular}

\section{Interpretasi}

Pada akhir siklus kedua hasil pembelajaran sudah memenuhi harapan, yakni peningkatan aktivitas dan ketuntasan belajar siswa secara individu maupun kelompok serta peningkatan keterampilan kooperatif/kerjasama dengan adanya kelompok super.

Hasil penelitian menunjukkan bahwa penerapan model pembelajaran kooperatif STAD efektif digunakan untuk meningkatkan ketuntasan belajar kimia siswa pada pokok bahasan termokimia. Secara keseluruhan penelitian menunjukkan adanya peningkatan baik dari aktivitas, keterampilan kooperatif/kerjasama, maupun hasil belajar siswa.

Pada siklus I, rata-rata hasil belajar siswa sebesar 74,49 dengan nilai tertinggi 95 dan nilai terendah 60. Berdasarkan tingkat penguasaan dan daya serap siswa terhadap materi pelajaran menunjukkan $17,95 \%$ siswa yang belum tuntas dan $82,05 \%$ yang telah tuntas, sehingga disimpulkan pada siklus I secara kelas siswa belum mencapai ketuntasan belajar. Setelah dilakukan pembelajaran siklus II, hasil belajar siswa meningkat dengan rata-rata sebesar 80,38 dengan nilai tertinggi 90 dan nilai terendah 65 serta ketuntasan siswa baik secara individu maupun klasikal sudah mencapai ketuntasan sebesar 100\%. Secara ringkas disajikan pada tabel 7 dan Gbr 2.

Tabel 7

Ringkasan ketuntasan dan hasil belajar siswa

\begin{tabular}{cccc}
\hline Siklus & $\begin{array}{c}\text { Rata-rata } \\
\text { Hasil Belajar } \\
\text { Siswa }\end{array}$ & $\begin{array}{c}\text { Persentase } \\
\text { Ketuntasan } \\
\text { Belajar }\end{array}$ & Keterangan \\
\hline I & 74,49 & $82,05 \%$ & $\begin{array}{l}\text { Belum tuntas } \\
\text { secara kelas }\end{array}$ \\
II & 80,38 & $100 \%$ & $\begin{array}{l}\text { Telah tuntas } \\
\text { secara kelas }\end{array}$ \\
\hline
\end{tabular}

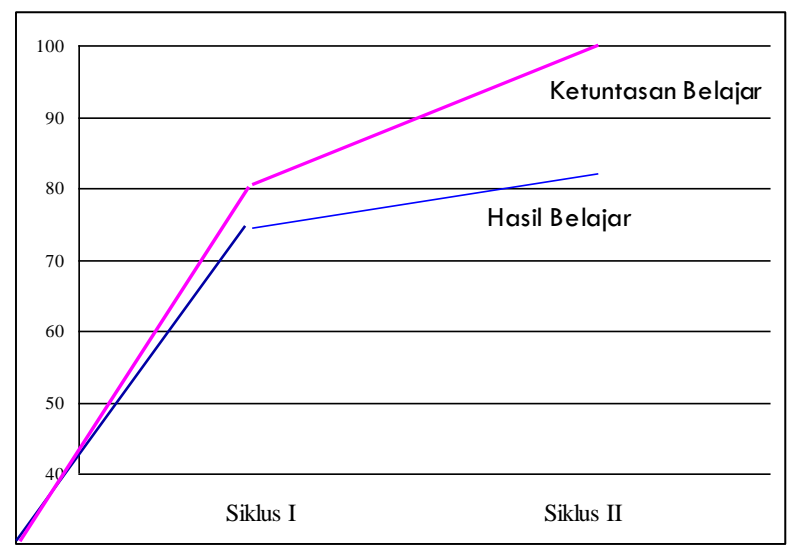

Gbr 2. Grafik Peningkatan Ketuntasan dan Hasil Belajar Siswa

Aktivitas belajar siswa selama proses pembelajaran diamati oleh dua orang pengamat (teman sejawat), menunjukkan adanya peningkatan aktivitas siswa. Hasil pengamatan oleh pengamat I 
di pada siklus I terlihat rata-rata 30 orang $(76,9 \%)$ aktif, dan oleh pengamat II rata-rata 31 orang $(79,5 \%)$ yang aktif dari masing-masing kategori aspek yang diamati. Selanjutnya setelah dilakukan siklus II menunjukkan adanya peningkatan aktivitas siswa yaitu menurut pengamat I rata-rata 38 orang $(97,4 \%)$ yang aktif, sementara menurut pengamat II rata-rata 37 orang $(94,9 \%)$ yang aktif dari masing-masing kategori aspek yang diamati.

Peningkatan aktivitas belajar siswa berdasarkan hasil pengamatan oleh pengamat I dan pengamat II ditunjukkan pada Gbr 3.

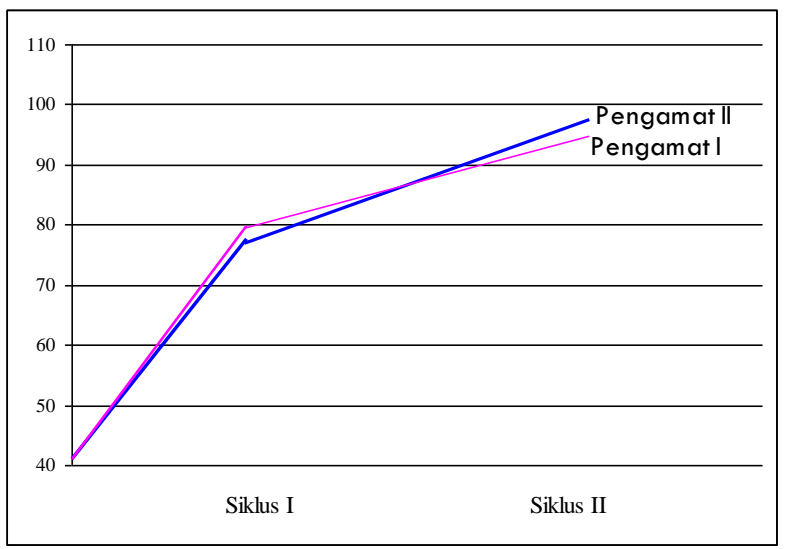

Gbr 3. grafik peningkatan aktivitas belajar siswa

\section{Kesimpulan}

Kesimpulan yang dapat ditarik dari PTK ini adalah sebagai berikut: (1) Penerapan model pembelajaran kooperatif STAD efektif digunakan dalam meningkatkan ketuntasan belajar kimia siswa pada pokok bahasan termokimia; (2) Ratarata hasil belajar siswa pada siklus I sebesar 74,49 dan meningkat dengan rata-rata sebesar 80,38 pada siklus II; (3) Ketuntasan hasil belajar siswa pada siklus I sebesar $82,05 \%$ (belum tuntas secara klasikal) dan pada siklus II ketuntasan hasil belajar siswa sebesar 100\% (telah tuntas secara klasikal); dan (4) Aktivitas belajar siswa selama pembelajaran dari siklus I hingga siklus II dengan menerapkan model pembelajaran kooperatif STAD mengalami peningkatan. Pada siklus I 76,9\% (pengamat I) dan 79,5\% (pengamat II)yang aktif. Sedangkan pada siklus $97,4 \%$ (pengamat I) dan $94,9 \%$ (pengamat l) yang aktif dari masing-masing kategori aspek yang diamati.

\section{Daftar Pustaka}

Ahmadi, A. \& Prasetya, J.T. (1997). Strategi Belajar Mengajar Untuk Fakultas Tarbiyah Komponen MKDK. Pustaka Setia, Bandung.

Aqib, Z. (2006). Peneltian Tindakan Kelas Untuk Guru. CV. Yrama Widya, Bandung.
Dimyati \& Mudjiono. (1999). Belajar dan Pembelajaran. Rineka Cipta, Jakarta.

Djamarah, S.B. \& Zain, A. (2002). Strategi Belajar Mengajar. Rineka Cipta, Jakarta.

Hamalik, O. (1990). Metode Belajar dan Kesulitan Belajar. Alumni, Bandung.

Ibrahim, H.M., Rachmadiarti, F. \& Ismono. (2000). Pembelajaran Kooperatif. UNESA-Universitas Press, Surabaya.

Jhonson, (1990). Pengantar Penelitian Dalam Pendidikan. Usaha Nasional, Surabaya

Kasbullah, K.E.S. (1998). Penelitian Tindakan Kelas. Dirien Dikti, Jakarta.

Lie, A. (2002). Cooperative Learning. Grasindo, Jakarta.

Manalu, E., Silaban, S., Silaban, R. \& Hutabarat, W. (2016). The Development of Chemical Practice Guidebook Colloid System-Based Integrated Contextual Character Values. Jurnal Pendidikan Kimia, 8(2):8-13.

Muslich, M. (2007). KTSP Pembelajaran Berbasis Kompetensi dan Kontekstual. Bumi Aksara, Jakarta.

Roestiyah, (1989). Strategi Belajar Mengajar. PT. Raja Grafindo Persada, Jakarta

Rusmansyah \& Irhasyuarna, Y. (2001). Penerapan Model Latihan Berstruktur Dalam Meningkatkan Pemahaman Siswa Terhadap Konsep Persamaan Reaksi.http://www.pdk.go.id/Jurnal/35/editorial. $\underline{\mathrm{htm}}$.

Silaban, S. \& Simangunsong, N.S.D. (2015). Pengaruh model pembelajaran Contextual Teaching and Learning (CTL) terhadap hasil belajar siswa pada pokok bahasan sistem koloid. Jurnal Pendidikan Kimia, 7(1): 1-7.

Slameto, (1995). Belajar dan Faktor-Faktor yang Mempengaruhinya. Rineka Cipta, Jakarta.

Sudjana, N. (1990). Model-Model Mengajar CBSA. Sinar Baru, Bandung.

Sukmadinata, S. (2004). Landasan Psikologi Proses Pendidikan. Remaja Rosdakarya, Bandung.

Suryosubroto, B. (1997). Proses Belajar Mengajar di Sekolah. Rineka Cipta, Jakarta.

Suyanto, (2002). Refleksi dan Reformasi Pendidikan di Indonesia Memasuki Millenium Ketiga. Adicita Karya Nusa, Yogyakarta.

Syahputra, (1998). Teori-teori Belajar. Erlangga, Jakarta.

Tim Pelatihan Proyek PGSM, (1999). Penelitian Tindakan Kelas (Classrom Action Reseach). Depdikbud, Jakarta.

User, U. (2000). Menjadi Guru Profesional, Remaja Rosdakarya, Bandung.

Wardhani, I.G.A.K., dkk. (2007). Materi Pokok Penelitian Tindakan Kelas. Universitas Terbuka, Jakarta.

Winkel, W.S. (2004). Psikologi Pengajaran. Media Abadi, Yogyakarta. 